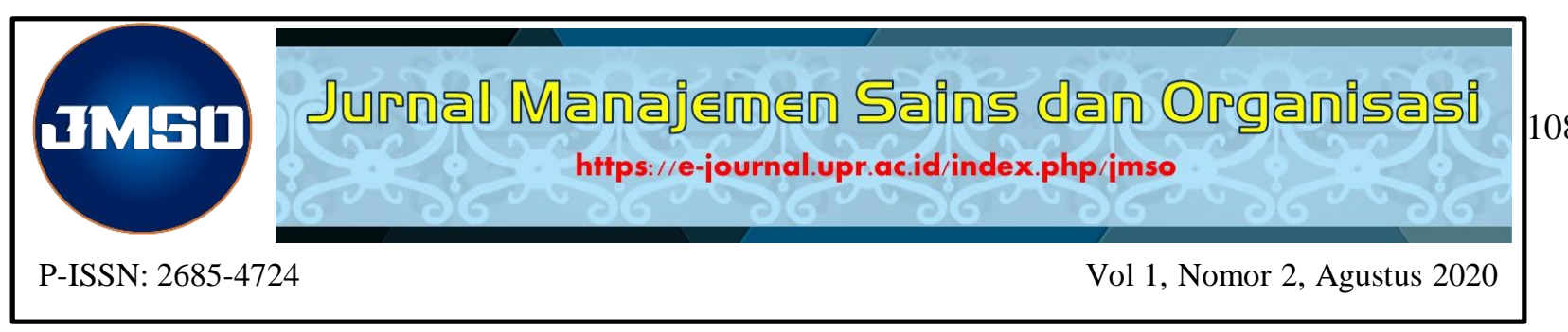

\title{
Analisis pengaruh kompensasi dan motivasi terhadap kinerja pegawai dengan perilaku melayani sebagai variabel intervening
}

\author{
Yemima \\ Magister Sains Manajemen \\ Universitas Palangka Raya, Indonesia \\ Email: yemima@gmail.com
}

\begin{abstract}
Abstrak
Tujuan - Penelitian ini bertujuan untuk menguji dan menganalisis pengaruh perilaku melayani dalam memediasi pengaruh antaran kompensasi dan kinerja pegawai, motivasi kerja dan kinerja pegawai.

Desain/Metodelogi/Pendekatan - Metode penelitian yang digunakan adalah pendekatan kualitatif yaitu pengumpulan data menggunakan kuesioner sebagai instrumen utama pengumpulan data untuk semua objek penelitian. Teknik pengambilan sampel dengan metode sensus. Responden yang digunakan adalah 42 pegawai di Dinas Pertanahan Kota Palangka Raya, dari 42 kuesioner yang tersebar, 40 kuesioner yang dikembalikan dan digunakan sebagai data penelitian. Teknik analisis data dalam penelitian ini menggunakan Structural Equation Modeling (SEM) dengan Variance Based Approaching atau Component Based with Partial Least Square (PLS).

Temuan - Hasil penelitian menunjukkan bahwa kompensasi berpengaruh positif terhadap kinerja karyawan, motivasi tidak berpengaruh terhadap kinerja karyawan, kompensasi berpengaruh positif terhadap perilaku melayani, perilaku melayani berpengaruh positif kinerja karyawan. Hubungan lainnya dijelaskan lebih lanjut.
\end{abstract}

Kata kunci: Kompensasi, perilaku melayani dan kinerja pegawai

\section{Investigation of the impact and inspiration on representative execution with serving conduct as an interceding variable}

\begin{abstract}
Purpose - This examination plans to inspect and investigate the impact of serving conduct in intervening the impact among remuneration and worker execution, work inspiration and representative execution.

Design / Methodology / Approach - The examination strategy utilized is a subjective methodology, in particular information assortment utilizing a survey as the fundamental instrument of information assortment for all exploration objects. The testing strategy utilized the statistics technique. Respondents utilized were 42 representatives in the Land Office of Palangka Raya City, from 42 polls dissipated, 40 surveys were returned and utilized as exploration information. The information investigation procedure in this examination utilized Structural Equation Modeling (SEM) with Variance Based Approaching or Component Based with Partial Least Square (PLS).

Findings - The outcomes showed that remuneration positively affected worker execution, inspiration had no impact on representative execution, pay positively affected serving conduct, administration conduct positively affected representative execution. Different connections are depicted further.
\end{abstract}

Keywords: Compensation, serving behavior and employee performance

Yemima. Published in the Jurnal Manajemen sains dan Organsasi. Published by FEB UPR Publishing Limited. This article is published under the Creative Commons Attribution (CC BY 4.0) licence. Anyone may reproduce, distribute, translate and create derivative works of this article (for both commercial and non-commercial purposes), subject to full attribution to the original publication and authors. 


\section{PENDAHULUAN}

Organisasi merupakan wadah kerjasama orang-orang dengan maksud untuk mencapai tujuan yang telah ditentukan secara bersama-sama. Setiap organisasi memerlukan kemampuan yang unggul untuk mencapai tujuan organisasi. Organisasi pada umumnya percaya bahwa untuk mencapai keunggulan harus mengusahakan kinerja individual yang setinggi-tingginya, karena pada dasarnya kinerja individual mempengaruhi kinerja tim atau kelompok kerja dan pada akhirnya mempengaruhi kinerja organisasi secara keseluruhan. Untuk itu, organisasi perlu menciptakan suatu lingkungan internal yang kondusif dengan harapan membuat para anggota atau karyawannya saling berkolaborasi positif guna membantu organisasi menciptakan efisiensi kerja yang baik. Namun dalam kenyataan sehari-hari, kinerja tinggi bagi pegawai bukanlah hal yang mudah untuk dicapai. Banyak hal yang menghalangi seorang pegawai mencapai kinerja tinggi tersebut. Sarana dan prasarana yang lengkap hingga mahal tidak selamanya mampu memberikan kontribusi yang berarti bagi keberhasilan organisasi manakala pegawai yang menjalankannya tidak memiliki kapabilitas. Apalagi dalam era globalisasi saat ini menuntut efektifitas dan efisiensi organisasi yang tinggi untuk dapat bertahan hidup di tengah-tengah tingkat persaingan yang sangat ketat (hypercompetition) antar organisasi. Perlu dilakukan perubahan internal organisasi untuk mengimbangi perubahan eksternal yang sedang berlangsung pesat saat ini.

Namun demikian, usaha perubahan organisasi yang membutuhkan partisipasi dari semua pegawai itu akan tercapai bila juga ada kemauan dari masing-masing individu pegawai untuk berperan sebagai agen perubahan, tidak hanya sekedar mengandalkan kemampuannya saja. Kemampuan tanpa didukung dengan kemauan, tidak akan menghasilkan peningkatan apapun. Kemauan pegawai untuk berpartisipasi dalam organisasi, biasanya tergantung pada tujuan apa yang ingin diraihnya dengan bergabung dalam organisasi bersangkutan. Kontribusi pegawai terhadap organisasi akan semakin tinggi bila organisasi dapat memberikan apa yang menjadi keinginan pegawai. Dengan kata lain, kemauan pegawai untuk memberikan sumbangan kepada tempat kerjanya sangat dipengaruhi oleh kemampuan organisasi dalam memenuhi tujuan dan harapanharapan pegawainya. Untuk itu, hal utama yang harus diperhatikan seorang manajer atau pimpinan organisasi adalah membangkitkan motivasi kerja karyawannya. Peranan manajer sangat besar dalam memotivasi pegawainya agar bekerja sesuai dengan program yang telah ditetapkan oleh organisasi. Dua faktor yang dapat mempengaruhi kinerja karyawan yaitu faktor internal dan faktor eksternal. Faktor internal merupakan faktor yang berhubungan dengan sifat-sifat seseorang, meliputi sikap, sifat-sifat kepribadian, sifat fisik, keinginan atau motivasi, umur, jenis kelamin, pendidikan, pengalaman kerja, latar belakang budaya dan variabel-variabel personal lainnya. Faktor eksternal merupakan faktor-faktor yang mempengaruhi kinerja karyawan yang berasal dari lingkungan, kepemimpinan, tindakan-tindakan rekan kerja, jenis latihan dan pengawasan, sistem upah dan lingkungan sosial.

Motivasi memiliki hubungan yang erat dengan sikap dan perilaku yang dimiliki oleh seseorang. Sikap yang ada pada setiap individu berinteraksi dengan nilai- nilai, emosi, peran, struktur sosial dan peristiwa-peristiwa baru, yang bersama-sama dapat dipengaruhi dan diubah oleh perilaku. Perubahan sikap ini dimungkinkan karena pikiran manusia adalah suatu kekuatan kompleks yang dapat mengadaptasi, mempelajari, dan memproses setiap informasi dan perubahan baru yang diterimanya. Motivasi itu sendiri 
dapat diartikan sebagai keadaan dalam diri pribadi seseorang sehingga orang tersebut terdorong untuk melakukan suatu kegiatan atau aktivitas. Oleh karenanya, motivasi mempunyai sifat yang tidak akan lepas dari sifat manusia itu sendiri, dimana manusia secara individual mempunyai kualitas eksistensi diri yang berbeda-beda antara satu dengan yang lainnya. Tiap-tiap individu mempunyai latar belakang dan sikap yang berbeda terhadap rangsangan yang ada, sehingga motivasi yang muncul pada tiap-tiap individu pun berbeda-beda. Beberapa cara dapat digunakan para pemimpin untuk memberikan motivasi positif terhadap bawahannya, seperti penghargaan terhadap pekerjaan yang dilakukan, penghargaan khusus secara pribadi, kompentisi, partisipasi, kebanggaan atau kepuasan dan materi. Dalam konteks organisasi pemerintahan, apabila penyelenggara pemerintahan memiliki motivasi kerja yang tinggi diharapkan dapat memberikan pelayanan yang semakin baik dan memuaskan penerima layanan.

Aspek penting lainnya yang perlu diperhatikan oleh organisasi terkait dengan peran sumber daya manusia adalah masalah keadilan kompensasi. Khususnya keadilan kompensasi telah menjadi isu sentral yang banyak dibahas dalam berbagai literatur sumber daya manusia (Suhartini, 1999,p.113; Babakus et.al.1996). Hal ini dikarenakan masalah keadilan kompensasi akan berhubungan dengan kemampuan karyawan untuk memenuhi segala kebutuhan hidupnya sehari-hari. Selain itu, masalah keadilan kompensasi juga mengindikasikan kebijakan perusahaan atau organisasi dalam memperlakukan para karyawannya secara adil. Perusahaan atau organisasi yang baik adalah perusahaan yang mampu untuk memberikan "imbalan" yang sesuai dengan besarnya kontribusi yang disumbangkan oleh para karyawan terhadap perusahaan tersebut. Kepuasan terhadap keadilan kompensasi yang diterima dari karyawan merupakan elemen utama terciptanya kepuasan kerja. Artinya semakin puas seorang karyawan terhadap kompensasi yang diterimanya, maka akan semakin puas karyawan terhadap pekerjaannya. Ketidakpuasan terhadap kompensasi akan mengakibatkan penurunan daya tarik pekerjaan, dan hal ini secara tidak langsung sedikit banyak akan mengganggu kinerja karyawan. Kondisi seperti ini tentunya tidak diharapkan semua pihak (Suhartini, 1999).

Penelitian Babakus et.al. (1996) berhasil membuktikan bahwa keadilan kompensasi pada akhirnya akan mengarah pada munculnya kepuasan. Hal ini dimungkinkan, karena keadilan kompensasi akan mengakibatkan timbulnya motivasi dalam diri karyawan. Selanjutnya motivasi ini akan berakibat pada timbulnya kepuasan kerja karyawan dan perilaku dalam melayani pimpinan dan konsumen. Kepuasan terhadap keadilan kompensasi menjadi salah satu aspek yang patut diperhatikan oleh perusahaan atau organisasi. Jumlah keadilan kompensasi yang diterima pekerja (upah) merupakan faktor multivariable yang signifikan dan kompleks dalam kepuasan kerja. Upah yang diterima harus dapat memenuhi kebutuhan hidupnya sehari-hari dan tingkat upah yang diterima pekerja mencerminkan sejauh mana pihak manajemen perusahaan menghargai kontribusi pekerjaan seseorang dalam organisasi tempat mereka bekerja. Para pekerja akan merasa puas apabila sistem pengupahan dilakukan secara adil dan sesuai dengan harapannya. Keadilan kompensasi berfungsi tidak hanya sebagai upah atas balas jasa karena seseorang telah memberikan jasa kepada orang lain, tetapi juga untuk memotivasi karyawan dan juga untuk mempertahankan agar mereka tidak keluar dari perusahaan. Dengan adanya keadilan kompensasi yang sesuai dengan prestasi kerja karyawan maka diharapkan bahwa karyawan akan merasa puas sehingga mereka akan meningkatkan 
produktivitas mereka untuk keberhasilan dan kemajuan perusahaan.

Kompensasi bukan merupakan satu-satunya faktor yang berpengaruh terhadap kepuasan pegawai, akan tetapi diyakini bahwa kompensasi merupakan salah satu faktor penentu yang dalam menimbulkan kepuasan pegawai, yang tentu saja akan memotivasi pegawai untuk meningkatkan produktivitasnya dan kinerjanya. Jika pekerja merasa bahwa usahanya tidak dihargai, maka prestasi pegawai akan sangat dibawah kapabilitasnya. Kompensasi finansial di lingkungan Kantor Pertanahan Kota Palangkaraya memiliki kepastian hukum yang sudah diatur dalam Peraturan Pemerintah Nomor 15 Tahun 2012 tentang Peraturan Gaji PNS. Selain gaji tetap, kompensasi finansial yang diterima oleh pegawai Kantor Pertanahan Kota Palangkaraya dapat berupa honor kegiatan, contohnya honor dalam rangka pengukuran dan pemetaan kadastral yang sumber dananya berasal dari Penerimaan Negara Bukan Pajak (PNBP).

Membantu dan melayani adalah inti dari tugas pegawai Kantor Pertanahan Kota Palangkaraya, karena Kantor Pertanahan Kota Palangkaraya merupakan lembaga pemerintah di tingkat daerah yang berwenang dalam menyelenggarakan pengelolaan pertanahan khususnya yang berkaitan dengan pengelolaan penguasaan dan hak-hak atas tanah. Kantor Pertanahan Kota Palangkaraya sebagai organisasi publik, bertanggung jawab untuk memberikan pelayanan yang terbaik kepada masyarakat. Kantor Pertanahan Kota Palangkaraya memberikan pelayanan yang baik kepada pelanggan berdasarkan pada Peraturan Menteri Pendayagunaan Aparatur Negara Nomor 63/KEP/M.PAN/7/2003 tentang Pedoman Umum Penyelenggaraan Pelayanan Publik. Handayani (2000) menjelaskan ada hubungan antara minat kerja dan konsep diri dengan perilaku layanan karyawan pada konsumen, sehingga disarankan kepada karyawan, untuk lebih memahami perilaku dalam memberikan layanan kepada konsumen dengan banyak mencari informasi mengenai perilaku melayani, faktor-faktor yang mendukung tentang komunikasi, interaksi dengan orang lain, berekspresi muka yang baik, berpenampilan yang baik, dan cara yang tetap mempunyai rasa percaya diri yang baik.

\section{Kajian Pustaka}

Penelitian yang dilakukan oleh Suryo, 2007, menemukan semakin baik imbalan yang diterima pegawai maka akan berdampak kepada kinerjanya, demikian pula bila tingkat kepuasan kerja pegawai semakin tinggi maka akan semakin meningkatkan kinerja pegawai tersebut. Retnaningsing, 2007, menyimpulkan bahwa keadilan kompensasi lebih berpengaruh terhadap komitmen organisasi dibandingkan dengan peran kepemimpinan dan kepuasan kerja sehingga komitmen organisasi lebih berpengaruh terhadap kinerja, hasil penelitian ini mengindikasikan bahwa kompensasi yang adil akan menumbuhkan rasa nyaman dan mampu meningkatkan komitmennya yang berdampak pada hasil output yang baik berupa peningkatan kinerja karyawan. Devi, 2009, menyatakan bahwa kepuasan kerja berpengaruh terhadap komitmen organisasi, namun variabel motivasi menunjukan hasil yang tidak signifikan terhadap komitmen organisasi yang berdampak terhadap kinerja pegawai. Dimana hasil ini berlawanan dengan penelitian yang dilakukan oleh Doyle dan Wong (1998) yang mengemukakan bahwa tinggi rendahnya kinerja dipengaruhi oleh tinggi rendahnya motivasi yang dimiliki karyawan. Variabel kepuasan kerja dan motivasi menunjukan pengaruh yang signifikan positif terhadap kinerja karyawan. Di sisi lain, hubungan antara komitmen organisasional tidak signifikan positif terhadap kinerja karyawan. Ernawati, 2010, penelitiannya menunjukkan variabel 
motivasi kerja berpengaruh negatif terhadap kinerja pegawai dan dari hasil uji t variabel motivasi kerja tidak signifikan terhadap kinerja pegawai karena probability value 0,073>0,05. Penelitian yang dilakukan oleh Muslih, 2011, menunjukkan bahwa motivasi instrinsik dan ekstrinsik berpengaruh signifikan secara tidak langsung terhadap kinerja melalui kepuasan kerja. Dais, 2010, menyimpulkan bahwa kepuasan kompensasi berpengaruh positif terhadap perilaku melayani dan perilaku melayani berpengaruh positif terhadap kinerja karyawan. Artinya semakin tinggi perilaku melayani akan semakin tinggi pula kinerja karyawan. Sebaliknya, semakin rendah perilaku melayani maka akan semakin rendah pula kinerja karyawan. Karepesina, 2007, menyimpulkan bahwa motivasi kerja mampu ditingkatkan maka kualitas layanan civil yang memiliki aspek kecepatan, ketepatan, kemudahan dan keadilan akan meningkat pula. Motivasi kerja aparat yang dikaji berdasarkan aspek motif, pengharapan dan insentif memiliki hubungan yang erat dengan kualitas layanan civil. Disamping memiliki hubungan, motivasi kerja juga mempengaruhi kualitas layanan civil. Dengan demikian maka baik buruknya kualitas layanan civil pada Kecamatan Jailolo dan Kecamatanan Sahu Kabupaten Halmahera Barat tergantung kepada baik buruknya motivasi kerja aparatnya. Penelitian yang dilakukan oleh Mulyadi, menyimpulkan bahwa secara parsial perilaku birokrasi memberikan pengaruh lebih besar dibandingkan dengan budaya kerja terhadap kinerja pegawai Unit Pelayanan Pengadaan Barang dan Jasa Provinsi Jawa Barat. Artinya bahwa perilaku birokrasi lebih dominan dan menjadi prioritas utama dalam mempengaruhi terhadap kinerja pegawai dibandingkan budaya kerja pada Unit Pelayanan Pengadaan Barang dan Jasa Provinsi Jawa Barat. Adapun karakteristik perilaku birokrasi yang memberikan pengaruh paling besar sampai terkecil secara berurutan terhadap kinerja pegawai adalah kepuasan, pertangungjawaban,kedisiplinan, ketaatan dan ketekunan kerja. Karakteristik kepuasan pengaruhnya paling besar, artinya bahwa karakteristik ini paling dominan dan menjadi prioritas dalam mempengaruhi kinerja pegawai Unit Pelayanan Pengadaan Barang dan Jasa Provinsi Jawa Barat. Sedangkan karakteristik ketekunan kerja pengaruhnya paling kecil, artinya bahwa karakteristik ini tidak dominan dan tidak menjadi prioritas dalam mempengaruhi kinerja pegawai.

Kompensasi tidak hanya penting bagi pegawai, tetapi juga bagi organisasi, dapat dikatakan penting bagi pegawai karena besarnya kompensasi memberikan gambaran ukuran nilai kerja pegawai itu sendiri. Besar kecilnya kompensasi dapat mempengaruhi tingkat kepuasan pegawai. Jika kompensasi yang diterima kurang memadai maka akan dapat menurunkan kualitas pelayanan kepada masyarakat dan akhirnya dapat mempengaruhi kinerja pegawai. Pemberian kompensasi haruslah ditetapkan secara adil dan merata, yaitu dengan membandingkan antara prestasi yang dicapai masing-masing pegawai dengan kompensasi atau penghargaan yang diberikan organisasi. Apabila prestasi pegawai sebanding dengan penghargaan yang diberikan organisasi, maka dorongan pegawai untuk meningkatkan kinerjanya dapat dioptimalkan. Dengan kata lain, bila kompensasi yang diberikan sesuai dengan keadilan dan harapan pegawai, maka pegawai akan puas dan termotivasi untuk terus meningkatkan kinerjanya. Penelitian yang dilakukan Sudarwanti Retnaningsing (2007), menyatakan bahwa kompensasi yang adil akan menumbuhkan rasa nyaman dan mampu meningkatkan komitmennya yang berdampak pada hasil output yang baik berupa peningkatan kinerja karyawan.

Hubungan antara motivasi dengan perilaku melayani juga sangat penting, karena 
dengan motivasi ini diharapkan setiap individu pegawai mau bekerja keras dan antusias untuk mencapai produktifitas kerja yang tinggi. Tujuan pemberian motivasi antara lain: mendorong gairah dan semangat kerja karyawan, meningkatkan moral dan kepuasan kerja karyawan, meningkatkan produktifitas kerja karyawan, meningkatkan loyalitas dan kestabilan karyawan perusahaan, meningkatkan kedisiplinan dan menurunkan tingkat absensi karyawan, mengefektifkan pengadaan karyawan, menciptakan suasana dan hubungan kerja yang baik, meningkatkan kreatifitas dan partisipasi karyawan, meningkatkan tingkat kesejahteraan karyawan, mempertingggi rasa tanggung jawab karyawan terhadap tugas-tugasnya serta meningkatkan efisiensi penggunaan tanggungjawab karyawan terhadapa tugas-tugasnya.

Berdasarkan kerangka pemikiran teoritis yang telah diuraikan diatas, maka hipotesis yang diajukan dalam penelitian ini yaitu:

H1 : kompensasi berpengaruh terhadap kinerja pegawai Kantor Pertanahan Kota Palangkaraya.

H2 : motivasi berpengaruh terhadap kinerja pegawai Kantor Pertanahan Kota Palangkaraya.

H3 : kompensasi berpengaruh terhadap perilaku melayani pegawai Kantor Pertanahan Kota Palangkaraya.

H4 : motivasi berpengaruh terhadap perilaku melayani pegawai Kantor Pertanahan Kota Palangkaraya.

H5 : perilaku melayani berpengaruh terhadap kinerja pegawai Kantor Pertanahan Kota Palangkaraya.

H6: kompensasi berpengaruh terhadap kinerja pegawai Kantor Pertanahan Kota Palangkaraya melalui perilaku melayani pegawai Kantor Pertanahan Kota Palangkaraya.

H7 : Motivasi berpengaruh terhadap kinerja pegawai Kantor Pertanahan Kota Palangkaraya melalui perilaku melayani pegawai Kantor Pertanahan Kota Palangkaraya.

\section{Metode Penelitian}

Jenis penelitian ini adalah penelitian kuantitatif dengan analisis kausalitas, dimana tujuan penelitian ini untuk mencari pengaruh antara beberapa variabel bebas dengan variabel terikat (Sugiyono, 2006). Peneliti mengumpulkan data dengan menggunakan kuesioner sebagai instrument pengumpulan data utama kepada obyek penelitian dan dibatasi dengan kajian manajemen sumberdaya manusia dengan menggunakan empat variabel penelitian. Populasi dalam penelitian ini adalah seluruh pegawai Kantor Pertanahan Kota Palangkarya yang berjumlah 42 orang. Unit analisis yang dipilih menjadi objek penelitian ini adalah seluruh pegawai pada Kantor Pertanahan Kota Palangkaraya, berjumlah 42 orang. Mengingat populasi yang relatif sedikit maka untuk memperoleh data yang valid dan reliabel, maka seluruh populasi menjadi responden. Dari 42 kuisioner yang disebarkan yang kembali sebanyak 40 kuisioner yang dijadikan data dalam peneltian ini. Dari 40 sampel dalam penelitian digunakan untuk mendapatkan gambaran yang lebih representatif sehingga data yang diperoleh mendekati nilai sesungguhnya dan tingkat kesalahannyapun semakin kecil. Jumlah 40 sampel ini juga telah memenuhi syarat untuk analisis, dengan 4 variabel yang digunakan dalam penelitian ini Roscoe (dalam Sekaran, 2006) menyatakan "Dalam penelitian multivariat ukuran 
sampel sebaiknya beberapa kali, 10x atau lebih dari jumlah variabel dalam studi." Variabel Kompensasi, Kompensasi merupakan bentuk penghargaan yang diberikan kepada karyawan sebagai balas jasa atas kontribusi yang mereka berikan kepada organisasi.

Variabel Motivasi, Motivasi itu sendiri dapat diartikan sebagai keadaan dalam diri pribadi seseorang sehingga orang tersebut terdorong untuk melakukan suatu kegiatan atau aktivitas.

Variabel Perilaku Melayani, Perilaku adalah tingkah laku, kelakuan, perbuatan; sedangkan melayani adalah menolong, meladeni, menyediakan segala apa yang diperlukan orang lain atau konsumen ( Poerwadarminto dalam Willy Lutfiani, 2008). Jadi variable perilaku melayani merupakan upaya maksimal yang dilakukan oleh pegawai dalam memberikan pelayanan untuk memenuhi harapan dan kebutuhan konsumen sehingga tercapai kepuasan tentang layanan yang diterima oleh konsumen. Variabel Kinerja, Variabel kinerja pegawai merupakan hasil kerja secara kualitas dan kuantitas yang dicapai seorang pegawai dalam melaksanakan tugasnya sesuai dengan tanggung jawab yang diberikan kepadanya.

Untuk menguji hipotesis dan menghasilkan suatu model yang layak ( $f i t$ ), penelitian ini menggunakan Structural Equation Modeling (SEM) dengan pendekatan variance based atau component based dengan Partial Least Square (PLS). Dengan menggunakan Partial Least Square (PLS) merupakan soft analisis. Hal ini dimungkinkan karena olgaritma dalam PLS menggunakan analisis series ordinary least square sehingga identifikasi model bukan masalah dalam model rekursif dan tidak mengasumsikan bentuk distribusi tertentu dari pengukuran variabel. Selanjutnya efisiensi perhitungan olgaritma mampu mengestimasi model yang besar dan kompleks (Falk and Miller, 1992 dalam Gozali, 2006). Dengan pendekatan PLS diasumsikan bahwa semua ukuran variance adalah variance yang berguna untuk dijelaskan. Oleh karena pendekatan untuk mengestimasi variabel laten dianggap sebagai kombinasi linear dari indikator, maka dapat menghindari masalah indeterminasi dan memberikan definisi yang pasti dari komponen skore. Partial Least Square (PLS) merupakan pendekatan yang lebih tepat untuk tujuan prediksi terutama pada kondisi di mana indikator bersifat formatif. Dengan variabel laten berupa kombinasi linier dari indikatornya, maka prediksi nilai dari variabel laten dapat dengan mudah diperoleh sehingga prediksi terhadap variabel laten yang dipengaruhinya juga dapat dengan mudah dilakukan. Hal itu berbeda dengan Structural Equation Modeling (SEM) yang indikatornya bersifat refleksif. Artinya perubahan nilai dari suatu indikator sangat sulit untuk mengetahui perubahan nilai dari variabel laten sehingga pelaksanaan prediksi sulit dilakukan. Melalui pendekatan PLS (berbasis varian) diasumsikan bahwa semua varian yang dihitung merupakan varian yang berguna untuk penjelasan. Pendekatan pendugaan variabel laten dalam PLS adalah sebagai exact kombinasi linier dari indikator sehingga mampu menghindari masalah indeterminacy dan menghasilkan skor komponen yang tepat. Dengan menggunakan algoritma iteratif yang terdiri atas beberapa analisis dengan metode kuadrat terkecil biasa (ordinary least square) maka persoalan identifikasi tidak menjadi masalah karena model bersifat rekursif.

\section{HASIL DAN PEMBAHASAN}

Evaluasi Measurement (Outer Model) 


\section{Uji Validitas}

Menurut Sugiyono (2006) Uji Validitas adalah suatu langkah pengujian yang dilakukan terhadap isi (conten) dari suatu instrument, dengan tujuan untuk mengukur ketepatan dan kecermatan suatu intrumen pengukuran dalam melakukan fungsi ukurnya dan agar data yang diperoleh bisa relevan/sesuai dengan tujuan diadakannya pengukuran tersebut. Suatu indikator dinyatakan valid jika mempunyai loading factor di atas 0,7 terhadap konstruk yang dituju. Output SmartPLS untuk loading factor memberikan hasil tabel berikut ini:

Tabel 1. Result for Outer Loading

\begin{tabular}{|c|c|c|c|c|c|}
\hline Indikator & Kompensasi & Motivasi & $\begin{array}{l}\text { Perilaku } \\
\text { melayani }\end{array}$ & Kinerja & Keterangan \\
\hline $\mathrm{X} 1.12$ & 0.775 & & & & valid \\
\hline $\mathrm{X} 1.13$ & 0.892 & & & & valid \\
\hline X1.15 & 0.722 & & & & valid \\
\hline $\mathrm{X} 1.16$ & 0.858 & & & & valid \\
\hline X1.17 & 0.857 & & & & valid \\
\hline $\mathrm{X} 2.1$ & & 0.724 & & & valid \\
\hline $\mathrm{X} 2.2$ & & 0.868 & & & valid \\
\hline $\mathrm{X} 2.3$ & & 0.763 & & & valid \\
\hline Y1.1 & & & 0.914 & & valid \\
\hline Y1.2 & & & 0.950 & & valid \\
\hline Y1.3 & & & 0.816 & & valid \\
\hline $\mathrm{Y} 2.2$ & & & & 0.768 & valid \\
\hline Y2.5 & & & & 0.827 & valid \\
\hline Y2.6 & & & & 0.772 & valid \\
\hline
\end{tabular}

\section{Uji Reliabilitas}

Uji reliabilitas dilakukan dengan melihat nilai composite reliability dari blok indikator yang mengukur konstruk. Hasil composite reliability akan menunjukkan nilai yang memuaskan jika di atas 0,7 . Berikut adalah nilai composite reliability pada output:

\begin{tabular}{cll} 
Tabel 2 Composite Reliability & \\
\cline { 2 - 3 } Konstruk & Composite Reliability & Keterangan \\
\hline Kompensasi & 0.913 & Reliabel \\
Motivasi & 0.829 & Reliabel \\
Perilaku melayani & 0.923 & Reliabel \\
Kinerja & 0.832 & Reliabel \\
\hline
\end{tabular}

Berdasarkan tabel tersebut dapat diuraikan bahwa hasil pengujian composite reliability menunjukkan nilai yang memuaskan, yaitu semua variabel laten telah reliabel karena seluruh nilai variabel laten memiliki nilai composite reliability $\geq 0,7$. Hal itu berarti bahwa, kuisioner yang digunakan sebagai alat dalam penelitian ini telah andal atau konsisten. Dengan demikian, dapat disimpulkan bahwa seluruh indikator memang menjadi pengukur konstruknya masing-masing. 
Metode lain untuk melihat discriminant validity adalah dengan melihat nilai square root of average variance extracted (AVE). Nilai yang disarankan adalah nilai di atas 0,5. Berikut adalah nilai AVE dalam penelitian ini yang ditunjukkan pada tabel 3.

Tabel 3. Average Variance Extracted (AVE)

\begin{tabular}{lll}
\hline Konstruk & Average variance extracted (AVE) & Keterangan \\
\hline Kompensasi & 0.678 & Reliabel \\
Motivasi & 0.620 & Reliabel \\
Perilaku & 0.801 & Reliabel \\
Kinerja & 0.624 & Reliabel \\
\hline
\end{tabular}

Tabel di atas memberikan konstruk nilai AVE di atas 0,5 pada variabel kompensasi, motivasi, perilaku melayani dan kinerja yang berarti memiliki nilai discriminant validity yang cukup.

\section{Pengujian Model Struktural (Inner Model)}

Setelah model yang diestimasi memenuhi kriteria Outer Model, berikutnya dilakukan pengujian model structural (Inner Model). Berikut adalah nilai R-square pada konstruk:

Tabel 4. Nilai $R^{2}$ Variabel Endogen

\begin{tabular}{ll}
\hline Konstruk & R-square \\
\hline Perilaku melayani & 0.628 \\
Kinerja & 0.581 \\
\hline
\end{tabular}

Tabel di atas memberikan nilai 0,628 untuk konstruk Perilaku melayani yang berarti bahwa Kompensasi dan Motivasi mampu menjelaskan variant Perilaku sebesar 62,82\%. Nilai R juga terdapat pada variabel Kinerja yang dipengaruhi oleh Kompensasi, Motivasi, dan Perilaku yaitu sebesar 0,581 (58,1\%).

Pengujian Goodness of Fit model structural pada inner model menggunakan nilai predictive-relevance $(\mathrm{Q} 2)$. Nilai $\mathrm{R} 2$ tiap-tiap variabel endogen dalam penelitian dihitung dengan menggunakan rumus berikut ini.

Predictive-relevance diperoleh dengan rumus:

$\mathrm{Q}^{2}=1-\left(1-\mathrm{R}_{1}{ }^{2}\right)\left(1-\mathrm{R}_{\mathrm{p}}{ }^{2}\right)$

$\mathrm{Q}^{2}=1-(1-0,628)(1-0,581)$

$\mathrm{Q}^{2}=0,844$

Hasil perhitungan di atas memperlihatkan nilai predictive-relevance sebesar 0,844 $(>0)$. Hal ini berarti bahwa $84,4 \%$ variasi pada variable kinerja (variabel dependen) dijelaskan oleh variabel-variabel yang digunakan. Dengan demikian model dikatakan layak memiliki nilai prediktif yang relevan.

Hasil pengujian hipotesis dengan Partial Least Square menunjukkan bahwa empat hipotesis dinyatakan signifikan. Pengujian hipotesis dilakukan dengan menggunakan uji t ( $t$-test) pada tiap-tiap jalur pengaruh antara variabel dependen dengan variabel independen. Hasil pengujian hipotesis tersebut ditunjukkan pada Tabel 5. 
Tabel 5 Hasil Pengujian Pengaruh Langsung

\begin{tabular}{llllll}
\hline Hubungan & $\begin{array}{l}\text { original } \\
\text { sample } \\
\text { estimate }\end{array}$ & $\begin{array}{l}\text { mean of } \\
\text { subsamples }\end{array}$ & $\begin{array}{l}\text { Standard } \\
\text { deviation }\end{array}$ & T-Statistic & Keterangan \\
$\begin{array}{l}\text { kompensasi -> perilaku } \\
\text { melayani }\end{array}$ & 0.759 & 0.732 & 0.100 & 7.594 & Diterima \\
$\begin{array}{l}\text { motivasi -> perilaku } \\
\text { melayani }\end{array}$ & -0.201 & -0.230 & 0.118 & 1.697 & Ditolak \\
$\begin{array}{l}\text { kompensasi -> kinerja } \\
\text { motivasi -> kinerja }\end{array}$ & 0.462 & 0.450 & 0.109 & 4.226 & Diterima \\
$\begin{array}{l}\text { Perilaku melayani -> } \\
\text { kinerja }\end{array}$ & -0.058 & -0.023 & 0.152 & 0.383 & Ditolak \\
\hline
\end{tabular}

Hasil analisis menunjukkan kompensasi berpengaruh terhadap kinerja. Hal ini dapat dilihat dari nilai t hitung sebesar 4,226 lebih besar dari t tabel 1,96. Nilai original sampel estimate adalah 0,462 yang menunjukkan bahwa arah hubungan antara kompensasi dan kinerja adalah positif, dapat disimpulkan bahwa hubungan antara keduanya adalah searah dan sangat kuat. Artinya, semakin baik kompensasi yang diterima pegawai maka semakin meningkat kinerja pegawai tersebut. Dengan demikian Hipotesa $\mathrm{H} 1$ dalam penelitian ini yang menyatakan bahwa kompensasi berpengaruh terhadap kinerja pegawai Kantor Pertanahan Kota Palangkaraya dapat diterima.

Hasil analisis menunjukkan motivasi tidak berpengaruh terhadap kinerja. Hal ini dapat dilihat dari t hitung sebesar 0,383 lebih kecil dari t tabel 1,96. Hal ini tidak sesuai dengan penelitian yang dilakukan oleh Doyle dan Wong (Eva Kris Diana Devi, 2009) yang mengemukakan bahwa tinggi rendahnya kinerja dipengaruhi oleh motivasi yang dimiliki oleh karyawan. Dengan demikian Hipotesa H2 dalam penelitian ini yang menyatakan bahwa Motivasi berpengaruh terhadap kinerja pegawai Kantor Pertanahan Kota Palangkaraya tidak dapat diterima.

Hasil analisis menunjukkan bahwa kompensasi berpengaruh terhadap perilaku melayani. Hal ini dapat dilihat dari t hitung sebesar 7,594 lebih besar dari t tabel 1,96. Nilai original sampel estimate adalah 0,759 yang menunjukkan bahwa arah hubungan antara kompensasi dan perilaku melayani adalah positif, dapat disimpulkan bahwa hubungan antara keduanya adalah searah dan sangat kuat. Artinya, semakin baik kompensasi yang diterima oleh pegawai maka semakin baik pula perilaku melayani pegawai tersebut. Dengan demikian Hipotesa H3 dalam penelitian ini yang menyatakan bahwa kompensasi berpengaruh terhadap perilaku melayani Kantor Pertanahan Kota Palangkaraya dapat diterima.

Hasil analisis menunjukkan bahwa motivasi tidak berpengaruh terhadap perilaku melayani. Hal ini dapat dilihat dari t hitung sebesar 1.697 lebih kecil dari t tabel 1,96. Dengan demikian Hipotesa H4 dalam penelitian ini yang menyatakan bahwa motivasi berpengaruh terhadap perilaku melayani Kantor Pertanahan Kota Palangkaraya ditolak. Nilai original sampel estimate sebesar -0.201 yang menunjukkan bahwa arah hubungan antara perilaku melayani dan kinerja adalah negatif, dapat disimpulkan bahwa hubungan keduanya tidak searah, hal ini menunjukkan bahwa peningkatan atau penurunan motivasi 
tidak berpengaruh terhadap peningkatan atau penurunan perilaku melayani pegawai Kantor Pertanahan Kota Palangkaraya.

Hasil analisis menunjukkan bahwa perilaku melayani berpengaruh terhadap kinerja. Hal ini dapat lihat dari nilai t hitung sebesar 2.099 lebih besar dari t hitung 1,96. Nilai original sampel estimate sebesar 0.338 yang menunjukkan bahwa arah hubungan antara perilaku melayani dan kinerja adalah positif, dapat disimpulkan bahwa hubungan antara keduanya adalah searah dan sangat kuat. Artinya, semakin tinggi perilaku melayani maka semakin tinggi pula kinerja pegawai. Dengan demikian Hipotesa H5 dalam penelitian ini yang menyatakan bahwa kompensasi berpengaruh terhadap perilaku melayani Kantor Pertanahan Kota Palangkaraya dapat diterima.

Selanjutnya dilakukan pengujian hipotesa tidak langsung melalui variabel interverning. Karena pada program Smart-PLS tidak dapat secara langsung menguji signifikansi tidak langsung maka dilakukan dengan penghitungan manual. Pengujian hipotesis mediasional berdasarkan signifikansi indirect effect pada PLS dilakukan secara manual. Uji signifikansi indirect effect $\mathrm{p} 1{ }^{*} \mathrm{p} 2$ didasarkan pada rasio antara koefisien p1*p2 dengan standard error-nya yang akan menghasilkan nilai z statistik (z-value). Standard error koefisien p1*p2 dihitung berdasarkan versi Aroian dari Sobel test yang dipopulerkan dan direkomendasikan oleh Baron and Kenny (1986), yaitu

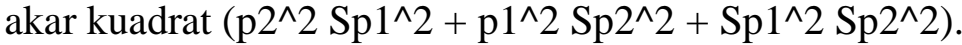

Dimana:

p1 : adalah koefisien path pengaruh variabel independen terhadap variabel mediasi p2 : adalah koefisien path pengaruh variabel mediasi terhadap variabel dependen Sp1:adalah standard error dari koefisien path $\mathrm{p} 1$

Sp2: adalah standard error dari koefisien path $\mathrm{p} 2$

Sobel dihitung menggunakan kalkulator Sobel-test yang dapat diakses gratis di web http://quantpsy.org/sobel/sobel.htm.

Tabel 6 Ringkasan Pengujian Pengaruh Tidak Langsung

\begin{tabular}{llll}
\hline Hubungan & $\begin{array}{l}\text { Test } \\
\text { statistik }\end{array}$ & P-Value & Keterangan \\
\hline $\begin{array}{l}\text { Kompensasi -> Kinerja-> Melalui } \\
\begin{array}{l}\text { Perilaku Melayani } \\
\text { Motivasi -> Kinerja-> Melalui Perilaku } \\
\text { Melayani }\end{array}\end{array}$ & 2,02 & 0,043 & Diterima \\
\hline
\end{tabular}

Dari tabel 5.15 hubungan antara variabel kompensasi dengan kinerja melalui perilaku melayani memiliki nilai t-statistik 2,02 lebih besar dari t tabel 1,96 dan p-value 0,043( $<0,05)$ sehingga dinyatakan hubungannya signifikan. Hal ini berarti kompensansi berpengaruh terhadap kinerja pegawai melalui perilaku melayani pegawai Kantor Pertanahan Kota Palangkaraya. Dengan demikian H6 dalam penelitian ini kompensasi berpengaruh terhadap kinerja pegawai Kantor Pertanahan Kota Palangkaraya melalui perilaku melayani pegawai Kantor Pertanahan Kota Palangkaraya dapat diterima. Dari tabel 5.15 hubungan antara variabel motivasi dengan kinerja melalui perilaku melayani memiliki nilai t-statistik 1,01 lebih kecil dari t tabel 1,96 dan p-value 0,31 (>0,05) sehingga dinyatakan hubungannya tidak signifikan. Hal ini berarti motivasi tidak berpengaruh terhadap kinerja melalui perilaku melayani. Dengan demikian H7 dalam penelitian ini motivasi berpengaruh terhadap kinerja pegawai Kantor Pertanahan Kota Palangkaraya melalui perilaku melayani pegawai Kantor Pertanahan Kota Palangkaraya 
tidak dapat diterima.

Hasil pengujian hipotesis menunjukkan bahwa kompensasi berpengaruh kuat dan positif terhadap kinerja pegawai Kantor Pertanahan Kota Palangka Raya. Ini berarti bahwa kompensasi yang digambarkan oleh pengakuan dari atasan atas hasil kerja, kemampuan menguasai pekerjaan dengan baik, mampu bekerja sama dalam team work untuk mecapai tujuan, mampu bekerja sama dengan rekan kerja dan organisasi menciptkan kenyamanan ruang perkantoran/ruang kerja berpengaruh kuat dan positif dalam meningkatkan kinerja pegawai. Kinerja digambarkan oleh pengambilan inisiatif, pencapaian kuantitas dan kualitas kerja, dan kemampuan diri mencapai tujuan. Hasil ini relevan dengan penelitian yang dilakukan oleh P. Suryo R. tentang analisis dampak imbalan dan kepuasan kerja terhadap kinerja pegawai Sekretariat Daerah Kabupaten Kutai Timur mengungkapkan bahwa semakin baik imbalan yang diterima pegawai maka akan berdampak kepada kinerjanya.

Hasil pengujian hipotesis menunjukkan bahwa motivasi tidak berpengaruh signifikan terhadap kinerja pegawai Kantor Pertanahan Kota Palangka Raya. Ini berarti bahwa motivasi yang digambarkan oleh kebutuhan akan rasa aman, pengakuan akan penghargaan dan kebutuhan untuk aktualisasi diri tidak berpengaruh dalam meningkatkan kinerja pegawai. Hal ini berarti peningkatan atau penurunan tingkat motivasi pegawai tidak memberikan pengaruh terhadap kinerja pegawai. Alasan penolakan hipotesa ini diduga bahwa data responden berdasarkan usia dan masa kerja pegawai dalam penelitian ini hasilnya 40 persen usia pegawai Kantor Pertanahan Kota Palangka Raya diatas 50 tahun dan 40 persen masa kerja di atas 25 tahun, dengan usia dan masa kerja demikian beberapa dari pegawai sudah mencapai masa puncak kariernya, sehingga dalam hal tuntutan motivasi bekerjanya atau berbuat untuk mencapai sesuatu yang lebih dalam kariernya tidaklah terlalu dipikirkan oleh mereka, yang ada dalam pikiran mereka bisa saja cukup bekerja sesuai tugas pokok dan fungsinya saja dan pekerjaan yang diberikan kepadanya dapat diselesaikan, sehingga hal ini sangat tidak berpengaruh bagi mereka dan kinerja merekapun tidak ada peningkatan. Hasil penelitian ini relevan dengan penelitian terdahulu yang dilakukan oleh Ernawati dimana hasil penelitiannya menunjukkan bahwa motivasi tidak berpengaruh positif dan tidak signifikan dan terhadap kinerja pegawai.

Hasil pengujian hipotesis menunjukkan bahwa kompensasi berpengaruh signifikan terhadap perilaku melayani pegawai Kantor Pertanahan Kota Palangkaraya. Ini berarti bahwa kompensasi yang digambarkan oleh pengakuan dari atasan atas hasil kerja, kemampuan menguasai pekerjaan dengan baik, mampu bekerja sama dalam team work untuk mecapai tujuan, mampu bekerja sama dengan rekan kerja dan organisasi menciptkan kenyamanan ruang perkantoran/ruang kerja berpengaruh kuat dan positif dalam meningkatkan perilaku melayani pegawai Kantor Pertanahan Kota Palangka Raya. Perilaku melayani digambarkan oleh sikap memberikan perhatian, sikap mendengarkan keinginan dan membantu yang diperlukan. Hasil ini relevan dengan penelitian terdahulu yang dilakukan oleh M. Chairul Dais dan hasil penelitiannya menunjukkan bahwa kompensasi berpengaruh positif terhadap perilaku melayani.

Hasil pengujian hipotesis menunjukkan bahwa motivasi tidak berpengaruh signifikan terhadap perilaku melayani pegawai Kantor Pertanahan Kota Palangkaraya. Ini berarti bahwa motivasi yang digambarkan oleh kebutuhan akan rasa aman, pengakuan akan 
penghargaan dan kebutuhan untuk aktualisasi diri tidak berpengaruh dalam meningkatkan perilaku melayani. Perilaku melayani digambarkan oleh sikap memberikan perhatian, sikap mendengarkan keinginan dan membantu yang diperlukan. Dalam hal ini berarti peningkatan atau penurunan tingkat motivasi pegawai tidak memberikan pengaruh terhadap perilaku melayani pegawai Kantor Pertanahan Kota Palangkaraya. Alasan penolakan hipotesa ini diduga bahwa data responden berdasarkan usia dan masa kerja pegawai dalam penelitian ini hasilnya 40 persen usia pegawai Kantor Pertanahan Kota Palangkaraya diatas 50 tahun dan 40 persen masa kerja di atas 25 tahun, dengan usia dan masa kerja demikian beberapa dari pegawai sudah mencapai masa puncak kariernya. Hal ini didukung oleh penelitian Puspa (2006) yang menyatakan bahwa pertanyaan pada kuesioner dengan ilustrasi-ilustrasi yang berbeda melatarbelakangi judgment dan persepsi masing-masing responden yang bervariasi walaupun pengalaman (lama kerja dan banyaknya penugasan) yang hampir sama ternyata memiliki pertimbangan yang berbeda-beda dan sangat bervariasi.

Hasil pengujian hipotesis menunjukkan bahwa perilaku melayani berpengaruh signifikan terhadap kinerja pegawai Kantor Pertanahan Kota Palangkaraya. Ini berarti bahwa Perilaku melayani digambarkan oleh sikap memberikan perhatian, sikap mendengarkan keinginan dan membantu yang diperlukan berpengaruh kuat dan positif dalam meningkatkan kinerja pegawai Kantor Pertanahan Kota Palangkaraya. Kompensasi yang digambarkan oleh pengakuan dari atasan atas hasil kerja, kemampuan menguasai pekerjaan dengan baik, mampu bekerja sama dalam team work untuk mecapai tujuan, mampu bekerja sama dengan rekan kerja dan organisasi menciptkan kenyamanan ruang perkantoran/ruang kerja. Hasil ini relevan dengan penelitian terdahulu yang dilakukan oleh Achmad Mulyadi yang hasil penelitiannya menunjukkan bahwa perilaku birokrasi lebih dominan dan menjadi prioritas utama dalam mempengaruhi terhadap kinerja pegawai.

Hasil penelitian menunjukkan bahwa kompensasi terhadap kinerja pegawai melalui perilaku melayani berpengaruh signifikan. Ini berarti bahwa kompensasi memberikan pengaruh secara tidak langsung kepada kinerja pegawai dengan melalui perilaku melayani sebagai intervening. Semakin tinggi kompensasi akan berdampak pada meningkatnya perilaku melayani dan akan berdampak pada meningkatnya kinerja pegawai. Hasil penelitian menunjukkan bahwa motivasi terhadap kinerja pegawai melalui perilaku melayani tidak berpengaruh signifikan. Hal ini berarti bahwa peningkatan atau penurunan motivasi tidak berdampak pada perilaku melayani dan tidak berdampak pada kinerja pegawai.

Berdasarkan hasil analisis diperoleh hasil bahwa kompensasi berpengaruh terhadap kinerja dan kompensasi berpengaruh terhadap perilaku melayani. Dalam hal ini secara teoritis penelitian ini telah mampu memprediksi bahwa kompensasi yang tinggi dapat meningkatkan kinerja pegawai dan kompensasi yang tinggi juga dapat meningkatkan perilaku melayani pegawai. Berdasarkan hasil analisis diperoleh hasil bahwa motivasi tidak berpengaruh terhadap kinerja pegawai, hal ini berarti untuk mencapai kinerja tidak memerlukan dukungan motivasi karena pencapaian kinerja dengan baik telah disadari oleh pegawai dan dapat dikatakan pegawai sudah mengetahui tugas pokok dan fungsi masing-masing. Berdasarkan hasil analisis diperoleh hasil bahwa perilaku melayani tidak memoderasi pengaruh variabel motivasi terhadap kinerja pegawai Kantor Pertanahan 
Kota Palangkaraya.

Hasil penelitian ini menunjukkan kompensasi yang tinggi mampu membentuk perilaku melayani pegawai Badan Pertanahan Kota Palangka Raya, ataupun secara langsung meningkatkan kinerja pegawai Badan Pertanahan Kota Palangka Raya. Namun motivasi belum mampu membentuk perilaku melayani dan berdampak menurunnya kinerja pegawai, sehingga diperlukan suatu usaha bagaimana cara untuk meningkatkan motivasi pegawai di lingkungan Kantor Pertanahan Kota Palangkaraya. Untuk memotivasi kerja pegawai perlu diperhatikan kebutuhan-kebutuhan individu untuk merealisasi potensi yang ada pada diri pegawai tersebut dengan memberikan penghargaan dan pemberian promosi jabatan bagi pegawai yang berprestasi.

\section{Keterbatasan Penelitian}

Penelitian ini telah berupaya untuk menyajikan model yang terintegrasi dan komprehensif tentang kompensasi dan motivasi terhadap kinerja pegawai melalui perilaku melayani pegawai. Namun disadari masih terdapat keterbatasan yang muncul dalam penelitian ini sehingga membuat hasil penelitian ini kurang sempurna. Keterbatasan penelitian ini dapat dilihat dari nilai prediktif model yang hanya $84,4 \%$ yang mengindikasikan bahwa keragaman data yang dapat dijelaskan oleh model tersebut sebesar $84,4 \%$ atau dengan kata lain informasi yang terkandung dalam data 84,4\% dapat dijelaskan oleh model tersebut. Sedangkan sisanya $15.6 \%$ dijelaskan oleh faktor dan variabel lain yang belum terkandung dalam model. Semua variabel penelitian diukur berdasarkan persepsi responden sehingga dapat menyebabkan bias data. Oleh sebab itu, perlu dilakukan penelitian lebih lanjut yang berkaitan dengan karakteristik individu dan motivasi lainya serta perilaku lainnya.

\section{SIMPULAN}

Kompensasi berpengaruh signifikan terhadap kinerja pegawai. Yang berarti semakin tinggi kompensasi maka kinerja pegawai semakin tinggi pula. Sebaliknya, semakin rendah kompensasi maka semakin rendah juga kinerja pegawai. Kompensasi berpengaruh signifikan terhadap perilaku melayani. Yang berarti, semakin tinggi kompensasi maka semakin tinggi perilaku melayani pegawai. Sebaliknya, semakin rendah kompensasi semakin rendah pula perilaku melayani pegawai. Motivasi tidak berpengaruh signifikan terhadap kinerja pegawai. Hal ini dapat dilihat dari t hitung sebesar 0,383 lebih kecil dari t tabel 1,96. Yang berarti, peningkatan atau penurunan tingkat motivasi pegawai tidak memberikan pengaruh terhadap kinerja pegawai. Motivasi tidak berpengaruh signifikan terhadap perilaku melayani. Hal ini dapat dilihat dari t hitung sebesar 1.697 lebih kecil dari t tabel 1,96. Yang berarti, peningkatan atau penurunan motivasi pegawai tidak memberikan pengaruh terhadap perilaku melayani pegawai. Perilaku melayani pegawai berpengaruh signifikan terhadap kinerja pegawai. Yang berarti, semakin tinggi perilaku melayani pegawai maka semakin tinggi pula kinerja pegawai. Sebaliknya, semakin rendah perilaku melayani pegawai semakin rendah kinerja pegawai. Kompensasi berpengaruh signifikan secara tidak langsung terhadap kinerja pegawai melalui perilaku melayani. Semakin tinggi kompensasi akan berdampak pada meningkatnya perilaku melayani dan melalui perilaku melayani akan berdampak pada meningkatnya kinerja pegawai. Motivasi tidak berpengaruh signifikan secara tidak langsung terhadap kinerja pegawai melalui kinerja. Hal ini bisa dilhat dari nilai t-statistik 
1,01 lebih kecil dari t tabel 1,96 dan p-value 0,31 lebih besar dari 0,05, yang berarti peningkatan atau penurunan motivasi pegawai tidak berdampak terhadap perilaku melayani dan tidak berdampak juga terhadap kinerja.

Peneliti mendatang hendaknya meneliti variabel motivasi lainnya yang tidak diteliti oleh peneliti. Menambahkan variabel kepuasan kerja dan variabel kemampuan dan kepemimpinan atau dipadukan dengan variabel budaya organisasi. Perlu melakukan penelitian dengan sampel yang lebih luas lagi, misal seluruh PNS di Kota Palangka Raya.

\section{REFERENSI}

Babakus, Emin, David W Cravens, Mark Johnston dan Wiliam C Moncrief. 1996. "Examining The Role of Organizational Variables in The Salesperson Job Satisfaction Model." Journal Of Personal Selling \& Sales Management Journal. Vol.XVI, No.3.

Djati, S. Pantja \& M Khusaini. 2003. "Kajian Ter-hadap Kepuasan Kompensasi, Komitmen Organisasi dan Prestasi Kerja", Jurnal Manajemen dan Kewirausahaan, Universitas Kristen Petra. http://fportfolio.petra.ac.id/ main.php?nip=91, (Akses 14 Maret 2013).

Devi,E.K.D. 2009. Analisis Tentang Pengaruh Kepuasan Kerja dan Motivasi Terhadap Kinerja Karyawan dan Komitmen Organisasional dengan Variabel Intervening pada Karyawan Outsourcing PT. Semeru Karya Buana Semarang. Tesis tidak diterbitkan. Semarang : Universitas Diponegoro.

Dais, M. Chairul. 2010. Pengaruh Kepuasan Kompensasi dan Perilaku Melayani dan Dampaknya Pada Kienerja Karyawan. Jurnal Ekonomi dan Bisnis. Vol 4. No. 3.

Ghozali, Imam, 2011. Aplikasi Analisis Multivariate dengan Progeam IBM SPSS 19. Edisi kelima. Semarang : Badan Penerbit Universitas Diponegoro.

Lutfiani, Willy, 2008. Pengaruh Kecerdasan Emosional Perawat Terhadap Perilaku Konsumen dan Kinerja Rumah Sakit Umum Daerah Kabupaten Indramayu. Jurnal Ekonomi dan Bisnis Volume 2 No. 3.

Latan, Hengky dan Imam Ghozali. 2013. Partial Least Squares Konsep Aplikasi Path Modelling Menggunakan Program XLSTAT-PLS. Semarang : Badan Penerbit Universitas Diponegoro.

Mas'ud, Fuad. 2004. Survei Diagnosis Organisasional (Konsep dalam Aplikasi). Semarang : Badan Penerbit Universitas Diponegoro.

Putra, Wicaksono, Adi. 2006. Analisis Pengaruh Kompensasi, Motivasi, dan Kepuasan Kerja Terhadap Kinerja Pegawai Negeri Sipil Pemerintah Kota Semarang. Tesis tidak diterbitkan. Semarang : Program Pasca Sarjana Program Studi Magister Sains Universitas Diponegoro.

Prihantoro, Mitro. 2011. Pengaruh Kompensasi Non Finansial Terhadap Semangat Kerja Anggota di Pussenkav Kodiklat TNI AD, Tesis tidak diterbitkan. Yogyakarta : Pascasarjana Universitas Gadjah Mada.

Retnaningsing, Sudarwanti. 2007. Analisis Pengaruh Keadilan Kompensasi, Peran Kepemimpinan, dan Kepuasan Kerja Terhadap Komitmen Organisasi Dalam Meningkatkan Kinerja Karyawan (Studi Kasus: Pada Sentral Pengolahan Pos Semarang). Tesis tidak diterbitkan. Semarang : Program Magister Manajemen 
Universitas Diponegoro.

Singh, J., W. Verbeke \& G.K. Rhoads.1996. "Do organizational practices matter in role stress processes? A study of direct and moderating effects for marketing-oriented boundary spanners", Journal of Marketing, Vo. 60, pp. 69-86.

Sugiyono. 2010. Metode Penelitian Kuantitatif, Kualitatif dan R\&D. Alfabeta. Bandung. Zeithaml, Valeri A. Parasuraman A dan Berry, Leonard L. 1990. Delivering Service Quality : Balancing Custumer Perceprtion and Expectations. New York : The Pree Press.

Sumber lain :

http://www.bpn.go.id

http://quantpsy.org/sobel/sobel.htm. 